\title{
Efficacy of Newer Molecules, Bioagents and Botanicals against Maydis Leaf Blight and Banded Leaf and Sheath Blight of Maize
}

\author{
Vinod Kumar Malik ${ }^{1 *}$, Manjeet Singh ${ }^{1}$, Karambir Singh Hooda ${ }^{2}$, Naresh Kumar Yadav ${ }^{1}$, and \\ Prashant Kumar Chauhan ${ }^{1}$ \\ ${ }^{I}$ Department of Plant Pathology, CCS Haryana Agricultural University, Hisar 125004, Haryana, India \\ ${ }^{2}$ Indian Institute of Maize Research, Pusa Campus, New Delhi 110012, India
}

(Received on December 1, 2017; Revised on January 5, 2018; Accepted on January 25, 2018)

Maize (Zea mays L.; 2N=20) is major staple food crop grown worldwide adapted to several biotic and abiotic stresses. Maydis leaf blight (MLB) and banded leaf and sheath blight (BLSB) are serious foliar fungal diseases may cause up to $40 \%$ and $100 \%$ grain yield loss, respectively. The present studies were undertaken to work out the efficacy of chemicals, botanicals and bioagents for the management of MLB and BLSB under field condition for two seasons Kharif 2014 and 2015. Five molecules (propiconazole 25 EC, hexaconazole 25 EC, carbendazim $50 \mathrm{WP}$, mancozeb $75 \mathrm{WP}$ and carbedazim $12 \mathrm{WP}$ + mancozeb $63 \mathrm{WP}$ ), two bioagents i.e. Trichoderma harzianum and $T$. viridae and three botanicals namely azadirachtin, sarpagandha and bel pathar were tested for their efficacy against MLB. Eight newer fungicides viz., difenconazole $250 \mathrm{SC}$, hexaconazole 5 EC, carbendazim 50WP, validamycin $3 \mathrm{~L}$, tebuconazole 250 EC, trifloxystrobin $50 \mathrm{WG}+$ tebuconazole $50 \mathrm{WG}$, azoxystrobin $250 \mathrm{EC}$ and pencycuron $250 \mathrm{SC}$ were evaluated against BLSB. Analysis revealed significant effects of propiconazole at $0.1 \%$, carbendazim $12 \mathrm{WP}$ + mancozeb 63 WP at $0.125 \%$ and sarpagandha leaves at $10 \%$ against MLB pathogen, whereas validamycin at $0.1 \%$ and trifloxystrobin $25 \mathrm{WG}+$ tebuconazole $50 \mathrm{WG}$ at $0.05 \%$ were found effective against BLSB. The slow rate of disease control virtually by the bioagents might

\footnotetext{
*Corresponding author.

Phone) 8295100390, FAX) 8295100390

E-mail)vmexcel@rediffmail.com

(c) This is an Open Access article distributed under the terms of the Creative Commons Attribution Non-Commercial License (http:// creativecommons.org/licenses/by-nc/4.0) which permits unrestricted noncommercial use, distribution, and reproduction in any medium, provided the original work is properly cited.
}

Articles can be freely viewed online at www.ppjonline.org. have not shown instant effect on plant response to the yield enhancing components. The identified sources of management can be used further in strengthening the plant protection in maize against MLB and BLSB.

Keywords: banded leaf and sheath blight, bioagents, botanicals, efficacy, maydis leaf blight, molecules

Handling Associate Editor : Sang, Mee Kyung

Maize is a versatile crop grown in different farming systems. It contributes a lot to nutritional food security of the society and is an important cereal crops of the world, grown in more than 150 countries. In India it is grown over an area of 9.26 million ha. It is one of the most important crops of the world and contributes a lot to food security in developing countries. It is being used as feed (63\%), food (23\%), starch industries (12\%), seed and miscellaneous uses $(2 \%)$ in India. The content of two essential amino acids i.e., lysine and tryptophan in quality protein maize makes its use essential for improvement of the nutritional quality of daily diet. In India, maize occupies an area of 9258 thousand hectares having production of 23673 thousand tones with an average productivity of $2.56 \mathrm{t} / \mathrm{ha}$. In Haryana, the crop occupies an area of 8.0 thousand hectares having production of 18 thousand tones with an average productivity of $2.25 \mathrm{t}$ /ha (Government of India, 2016). Recently, an increase in demand is reported and area under cultivation of corn viz., quality protein maize (QPM), pop corn (PC), sweet corn (SC) and baby corn (BC) along with normal yellow maize is also increasing. Use of maize as feed, food, fodder and specialty corn as pop corn, sweet corn, baby corns makes it one of the main crops par excellence for industrial use adapted to different agro-ecological and climatic conditions. 
The maize diseases of global importance that pose threats to maize yield and human health includes the fungal pathogens that attack the leaves, stem and ear (Balint-Kurti and Johal, 2009). The worldwide yield losses due to diseases in maize crop have been estimated at 4 to $14 \%$ of annual global harvest (Oerke, 2006). Maydis leaf blight, also named as southern corn leaf blight caused by the ascomycete fungus Cochliobolus heterostrophus (Drechs.) Drechs; synonym, Helminthosporium maydis Nisikado is a serious fungal disease of maize throughout the world where warm and humid conditions exists during crop growing season (White, 1999). It has now become one of the most prevalent and severe diseases in countries like Pakistan, India, Nepal, Indonesia, Vietnam and China. The crop grown in Kharif season in Indian subcontinent is prone to number of biotic factors like foliar diseases, stalk rots, and banded leaf and sheath blight where maydis leaf blight is the most important foliar disease in maize growing areas. In India, where tropical maize is cultivated, MLB and BLSB are major foliar threats to sustainable cultivation of maize. Maydis leaf blight appears in hills, plains and peninsular parts of the country. The currently predominant form of $C$. heterostrophus is Race $\mathrm{O}$, which can cause yield losses of up to $40 \%$ (Byrnes et al., 1989). Maydis leaf blight causes considerable losses in production and productivity of the crop. The incidence of another major threat i.e. banded leaf and sheath blight is also increasing in maize growing areas of the country. The disease BLSB, incited by Rhizoctonia solani f.sp. sasakii, has a potential to inflict the economic losses up to $100 \%$ (Sharma et al., 2002a). This disease has attained damaging status and has rapidly gained economic importance in several parts of the world (Kumar and Singh, 2004). Both the diseases are well noticed in various maize growing states of India included, Jammu and Kashmir, Himachal Pradesh, Punjab, Rajasthan and Delhi and Haryana. Earlier work has been done on management of both the major diseases, but keeping in view the present damaging status of the diseases, use of outdated molecules and increase in area under maize cultivation there is need to develop eco-friendly management practices.

Previously the use of fungicide was rare, but during the last decade maize production has seen an increase in use of foliar fungicides. As per scanty information several fungicides like carbendazim, benodanil and validamycin have been found effective in vitro and in vivo conditions against both the pathogens (Ahuja and Payak, 1986; Sharma and Rai, 1999). Recently, Reddy et al. (2013) conducted some management studies against turcicum leaf blight of maize and found that mancozeb $(0.25 \%)$ and carbendazim + mancozeb $(0.25 \%)$ were significantly superior over other treat- ments. Hulagappa (2012) tested eight fungicides against maydis leaf blight of maize and recorded minimum percent disease index in case of crop sprayed with propiconazole at $0.10 \%$. Nasir et al. (2012) tested nine fungicides screened in laboratory where propiconazole, chlorothalonil, triadimefon, mancozeb, carbendazim + moncozeb and thiram were found effective in reducing the radial growth of the Bipolaris sorokiniana. But when tested in vivo, only two fungicides namely propiconazole $(0.1 \%)$ and chlorothalonil $(0.2 \%)$ were found effective in reducing disease severity. Recently technologies including sarpagandha leaves at $10 \%$, Trichoderma harzianum $(\mathrm{TH}-3)$ at $0.5 \%$ as seed treatment + bioagents fortified FYM $(1: 50)$ and spray at $0.5 \%$, Trichoderma viride (TV-3) at $0.5 \%$ as seed treatment + bioagent fortified FYM (1:50) and spray at $0.5 \%$ and foliar application of propiconazole at $0.1 \%$, hexaconazole at $0.1 \%$, carbendazim at $0.1 \%$, mancozeb at $0.2 \%$, carbendazim $12 \mathrm{WP}+$ mancozeb $63 \mathrm{WP}$ at $0.125 \%$ are validated for effective management of maydis leaf blight disease of maize (ICAR- Indian Institute of Maize Research, 2016). Out of three often used fungicides, namely Bavistin, Rhizolex, and Thiophanate M, have shown absolute control of mycelial growth of $R$. solani f.sp. sasakii with $100 \%$ inhibition (Sharma et al., 2002a). Batsa et al. (2004) also studied about the comparative efficacy of cultural, chemical and biological control against BLSB in maize and found that the cost of control was minimum in leaf stripping however validamycin provided maximum (Rs 5.88) return from each rupee investment. Saxena (2002) tested efficacy of propiconazole $(0.1 \%)$ and carbendazim $(0.05 \%)$ and recorded remarkable effectiveness of propiconazole when the chemical was applied at initial stages at 30th or 40th day after planting and the second spray at 10 days after the first spray. Foliar sprays of carbendazim showed the ineffectiveness against BLSB. In recent year area under maize cultivation has increased and purported yield enhancement associated with quinine outside inhibitors (Qois) such as strobilurins have encouraged the use of foliar fungicides in the corn belt of America (Bradley, 2012).

Disease management through biological agents and botanical extracts is also of great importance. Several workers have reported antagonistic activities of Trichoderma spp against $R$. solani f.sp. sasakii (Subedi, 2015). Kumar et al. (2009) evaluated some plant extracts against maydis leaf blight under field condition and recorded significantly higher grain yield in plots sprayed with garlic clove extract (17.0 and $18.0 \mathrm{q} / \mathrm{ha})$, tulsi leaf extract (13.5 and $14.5 \mathrm{q} / \mathrm{ha})$ and neem leaf extract (16.0 and $15.3 \mathrm{q} / \mathrm{ha}$ ) as compared to unsprayed plots. Yield recorded in plot sprayed with onion bulb extract, bael leaf extract and mentha leaf extract were 
at par with control. Kumar et al. (2005) also found that $A$. indica was quite effective in reducing the alternaria leaf blight under field conditions. Leaf extract of Rauvolfia serpentine at $10 \%$ concentration, significantly inhibited the spore germination of Bipolaris sorokiniana and increased grain yield in wheat by $28.9 \%$ over the check when applied as foliar sprays in the field (Malik et al., 2008). Both the disease i.e. MLB and BLSB are well noticed in Indian farming systems and affecting the yield potential of maize. Due to non availability of stable sources of resistance to the diseases, control by chemical and biological means is important to avoid crop losses. Therefore, there is an immediate need to identify the suitable sources of management through biorational approaches and also to examine their efficacy for effective management. Attempts were made in the present study to find out the suitable chemical and biological control measures for effective management of MLB and BLSB diseases.

\section{Materials and Methods}

The present study consisted of three experiments conducted at CCS Haryana Agricultural University regional research station, Karnal during Kharif 2014 and 2015. In first experiment a mixture of maize inbred line HKI 1105 and HKI 536 CBT was sown in randomized block design (RBD, treatment- 6 , replication- 3 ) with plot size of $4 \mathrm{~m} \times 0.75 \mathrm{~m}$ $\times 4$ rows maintaining around 60 plants per plot to test the efficacy of five molecules namely propiconazole $25 \mathrm{EC}$, hexaconazole $25 \mathrm{EC}$, carbendazim $50 \mathrm{WP}$, mancozeb 75 WP and carbendazim $12 \mathrm{WP}+$ mancozeb $63 \mathrm{WP}$ in comparison to check (water spray) under artificially inoculated condition. The another set was laid down using one inbred line, HKI 1105 to study the effect of three botanicals (azadirachtin $3000 \mathrm{ppm}$ at $0.03 \%$, sarpagandha leaves at $10 \%$ and bel pathar at 25\%) and two bioagents \{(Trichoderma harzianum at $0.5 \%$ as seed treatment with bioagent fortified FYM $(1: 50)$ and spray at $0.5 \%$ and $T$. viride at $0.5 \%$ as seed treatment with bioagent fortified FYM $(1: 50)$ and spray at $0.5 \%)\}$. In third experiment single cross hybrid HM 4 was sown in randomized block design (treatment9 , replication-3) with plot size of $4 \mathrm{~m} \times 0.75 \mathrm{~m} \times 4$ rows to test the efficacy of eight molecules (viz., difenconazole 250 $\mathrm{SC}$ at $0.1 \%$, hexaconazole $5 \mathrm{EC}$ at $0.1 \%$, carbendazim 50 $\mathrm{WP}$ at $0.1 \%$, validamycin $3 \mathrm{~L}$ at $0.1 \%$, tebuconazole 250 $\mathrm{EC}$ at $0.05 \%$, trifloxystrobin $25 \mathrm{WG}+$ tebuconazole 50 WG at $0.05 \%$, azoxystrobin $250 \mathrm{EC}$ at $0.05 \%$ and pencycuron $250 \mathrm{SC}$ at $0.1 \%$ ) under artificially inoculated condition. The crop was raised by following all recommended practiceswith recommended dose of fertilizer and crop was kept free of weeds by weeding done manually. The MLB local isolate collected from previous year's naturally infected leaves was used to inoculate healthy maize plants at a stage of their 40-50 cm height, using sorghum grain culture method (Singh et al., 2004). In case of BLSB, the infected plant parts were collected from previous/current years naturally infected plants and the moist sheath blight infected plant bits were placed at the junction of sheath and lower leaf. Foliar application of the chemical, botanicals and bioagents were made after appearance of initial symptoms.

The diseases were rated at dough stage on 1-5 scale (Payak and Sharma, 1985; Shekhar and Kumar, 2012) and percent disease index (PDI) was calculated using the following formulae (Wheeler, 1969):

$\mathrm{PDI}=\frac{\mathrm{n} 1 \times 1+\mathrm{n} 2 \times 2+\mathrm{n} 3 \times 3+\mathrm{n} 4 \times 4+\mathrm{n} 5 \times 5}{\text { Total number of leaves observed } \times \text { Maximum grade }} \times 100$

Where, n1 to $\mathrm{n} 5$ represent total number of leaves falling under 1-5 scales, respectively.

Yield per plot was recorded at the harvest of the crop.

\section{Results}

The results on the efficacy of different fungicides, bioagents and botanicals was tested against maydis leaf blight and banded leaf and sheath blight, along with their effect on grain yield are presented as under:

Efficacy of fungicides on incidence of maydis leaf blight. A perusal of results indicates that all fungicides (propiconazole $25 \mathrm{EC}$, hexaconazole $25 \mathrm{EC}$, carbendazim $50 \mathrm{WP}$, mancozeb $75 \mathrm{WP}$ and carbendazim $12 \mathrm{WP}+$ mancozeb $63 \mathrm{WP}$ ) were found significantly effective in reducing the PDI in both the testing years. The result presented in Supplementary Table 1 revealed that during Kharif 2014 minimum percent disease index $(44.66 \%)$ was recorded in case of foliar spray with carbendazim $12 \mathrm{WP}+$ mancozeb 63 WP at $0.125 \%$. During Kharif 2015 lowest percent disease index $(44.90 \%)$ was recorded in case of propiconazole at $0.1 \%$ with maximum yield $(770.0 \mathrm{~kg} / \mathrm{ha})$ as compared to untreated check, closely followed by carbendazim 12 $\mathrm{WP}+$ mancozeb $63 \mathrm{WP}$ at $0.125 \%$ with PDI $(45.23 \%)$ and a yield of $760.0 \mathrm{~kg} / \mathrm{ha}$. Amongst the all five fungicides tested carbendazim $12 \mathrm{WP}+$ mancozeb $63 \mathrm{WP}$ at $0.125 \%$ and propiconazole at $0.1 \%$ gave highest disease control i.e. 40.67 and $37.50 \%$ for Kharif 2014 and 2015, respectively. A positive yield response was observed when fungicides were applied to corn plots. Maximum increase in yield was 
recorded with carbendazim $12 \mathrm{WP}+$ mancozeb $63 \mathrm{WP}$ at $0.125 \%$ (787.0 and $760.0 \mathrm{~kg} / \mathrm{ha}$ in Kharif 2014 and 2015, respectively) and propiconazole at $0.1 \%$ (775.0 and 770.0 $\mathrm{kg} / \mathrm{ha}$ in Kharif 2014 and 2015, respectively).

Efficacy of botanicals/bioagents on incidence of maydis leaf blight. Foliar diseases which rapidly spread and cause epidemics can be managed effectively by developing suitable disease management strategies. The experimental results of testing botanicals/bioagents against BLSB did not show higher disease control, therefore, are not presented and discussed in the article. All the botanicals/bioagents tested were found significantly effective in controlling the maydis leaf blight (Supplementary Table 2). Lowest PDI i.e. 46.58 and $46.28 \%$ for Kharif 2014 and 2015, respectively, was recorded when crop was sprayed with leaf extract $(10 \%)$ of medicinal plant sarpagandha (Rauvolfia serpentine) which was significantly lower than all the treatment, except $T V-3$ at $0.5 \%$ applied as seed treatment, bioagentsfortified FYM $(1: 50)$ and spray at $0.5 \%$ during both the seasons of testing. Significantly higher yield was also recorded in case of $R$. serpentine followed by $T V-3$ at $0.5 \%$ as seed treatment, bioagents-fortified FYM $(1: 50)$ and spray at $0.5 \%$. R. serpentine exhibited maximum control (35.81\%) of the disease during Kharif 2014. Plots sprayed with sarapgandha leaves extract yielded significantly higher i.e. 808.0 and $788.0 \mathrm{~kg} / \mathrm{ha}$ during Kharif 2014 and 2015, respectively. Azadirachtin 3000 ppm (commercially available formulation) applied at $0.3 \%$ gave 15.54 and $14.97 \%$ disease control over untreated plants for Kharif 2014 and 2015 , respectively.

Efficacy of newer fungicides on incidence of banded leaf and sheath blight. Eight new generation fungicides were tested at different concentrations. All the treatments reduced the PDI significantly as compared with check plot and the lowest percent disease index (43.56 and 36.57\%) was recorded in case of validamycin at $0.1 \%$ (Supplementary Table 3). It gave 46.50 (Kharif 2014) and 49.15 (Kharif 2015) percent disease control and also increased the yield up to $48.18 \%$ over unprotected plot. The yield ( $4650 \mathrm{~kg} / \mathrm{ha}$ ) recorded for validamycin at $0.1 \%$ was significantly higher than all the treatments in both the seasons; however hexaconazole at $0.1 \%$ during Kharif 2014 gave $4536.0 \mathrm{~kg} / \mathrm{ha}$ yield which was statistically at par to that of validamycin at $0.1 \%$ treatment. Lower yield was recorded in the plots sprayed with carbendazim. A combination of trifloxystrobin $25 \%+$ tebuconazole $50 \%$ at $0.05 \%$ also gave good control over disease during both the years. Whereas, lower yield was recorded for azoxystrobin at $0.05 \%$ and pencycuron at
$0.1 \%$.

\section{Discussion}

Earlier, minimum percent disease index in case of MLB have been recorded in case of crop sprayed with propiconazole at $0.10 \%$ (Hulagappa, 2012). Reddy et al. (2013) found mancozeb $0.25 \%$ and carbendazim + mancozeb $0.25 \%$ significantly superior over other treatments in reducing incidence of turcicum leaf blight incidence in maize. Nasir et al. (2012) tested nine fungicides in vivo and only two fungicides namely propiconazole $(0.1 \%)$ and chlorothalonil $(0.2 \%)$ were found effective in reducing disease severity. Present results are also in confirmation with findings of 59th annual maize workshop held on 10-12 April, 2016 at UAS, Bengaluru, Karnatka, where technologies including sarpagandha leaves at $10 \%$, Trichoderma viride (TV-3) at $0.5 \%$ as seed treatment + bioagent fortified FYM $(1: 50)$ and spray at $0.5 \%$ and foliar application of propiconazole at $0.1 \%$, hexaconazole at $0.1 \%$, carbendazim at $0.1 \%$, mancozeb at $0.2 \%$, carbendazim $12 \mathrm{WP}+$ mancozeb $63 \mathrm{WP}$ at $0.25 \%$ were validated for effective management of maydis leaf blight. Present findings revealed that yield enhancement has been associated with use of fungicides and results were in support with the findings of Bradley (2012).

Realizing the significance of disease management through biological agents and botanical extracts several workers had reported antagonistic activities of Trichoderma spp and different plant extracts (Kumar et al., 2005, 2009; Subedi, 2015). Leaf extract of $R$. serpentine at $10 \%$ concentration, has been quite effective in controlling the spot blotch of wheat incited by Bipolaris sorokiniana (Malik et al., 2008) and maydis leaf blight of maize (ICARIndian Institute of Maize Research, 2016) which encourages the present findings. With regards to disease control, sarapagandha leaf extract at $10 \%$ can safely be used instead of chemicals or as alternative to chemicals to encourage the eco-friendly control measures.

Earlier, several fungicides like use of carbendazim, benodanil and validamycin have been found effective against R. solani (Ahuja and Payak, 1986; Sharma and Rai, 1999). Batsa et al. (2004) also confirmed maximum return (Rs 5.88) from each rupee investment when BLSB infected maize crop was sprayed with validamycin. In present study also validamycin 3\% L and trifloxystrobin $25 \%$ + tebuconazole $50 \%$ gave good control over disease during both the years. Saxena (2002) also recorded superiority of propiconazole over normally used fungicide carbendazim.

In the present investigation, among the five fungicides, propiconazole $25 \mathrm{EC}$ at $0.1 \%$ and carbendazim $12 \mathrm{WP}+$ 
mancozeb $63 \mathrm{WP}$ at $0.125 \%$ gave best control of maydis leaf blight and significantly increased the grain yield. Sarpagandha leaves extract and Trichoderma viride were also found effective against MLB under field condition and can safely be used in place of fungicides for strengthening of integrated disease management of MLB. The lack of contribution of Trichoderma spp in yield enhancement of maize indicated that the antagonistic property of bioagent might have not provided instant plant response to the yield enhancement factors. In case of banded leaf and sheath blight validamycin $0.3 \% \mathrm{~L}$ at $0.1 \%$ and trifloxystrobin $25 \%+$ tebuconazole $50 \%$ at $0.05 \%$ were found effective in reducing the percent disease index and produced superior yield.

\section{Acknowledgments}

All sort of assistance rendered by Director, ICAR- Indian Institute of Maize Research, Ludhiana and Director of Research, Chaudhary Charan Singh Haryana Agricultural University, Hisar for the above study is gratefully acknowledged.

\section{References}

Ahuja, S. C. and Payak, M. M. 1986. In vitro response of maize and rice isolates of Rhizoctonia solani to antibiotics and fungi-toxicants. Int. Rice Res. New. 11:16-17.

Balint-Kurti, P. J. and Johal, G. S. 2009. Maize disease resistance. In: Handbook of maize: its biology, eds. by J. L. Bennetzen and S. C. Hake, pp. 229-250. Springer, NY, USA.

Batsa, B. K., Sharma, R. C. and Rai, S. N. 2004. Comparative efficacy of cultural, chemical and biological control against banded leaf and sheath blight in maize. In: Proceedings of the 24th national summer crops research workshop on maize research and production in Nepal, June 28-30, 2004, 232 pp. Kathmandu, Nepal.

Bradley, C. A. 2012. Factors considered when making corn fungicide application decisions in Illinois. J. Extension 50:3RIB7.

Byrens, K. J., Pataky, J. K. and White, D. G. 1989. Relationships between yield of three maize hybrids and severity of southern leaf blight caused by race $\mathrm{O}$ of Bipolaris maydis. Plant Dis. 73:834-840.

Government of India. 2016. Statistical year book India 2014-15. Ministry of Statistics and Programme implementation, Govt. of India. URL http://www.mospi.gov.in/download-reports/.

Hulagappa. 2012. Studies on maydis leaf blight of maize caused by Drechslera maydis (Nisikado) Subram. and Jain. MSc thesis. University of Agricultural Sciences, Dharwad.

ICAR-Indian Institute of Maize Research. 2016. Proceedings of 59th annual maize workshop (held at University of Agricul- ture Sciences, 10-12 April 2016). Bèngaluru.

Kumar, R. and Singh, I. S. 2004. Genetic control of banded leaf and sheath blight (Rhizoctonia solani f. sp. sasakii) in maize (Zea mays L.). Cereal Res. Commun. 32:309-316.

Kumar, S., Rani, A. and Jha, M. M. 2009. Evaluation of plant extracts for management of maydis leaf blight of maize. Ann. Pl. Protec. Sci. 17:130-132.

Kumar, S., Upadhyay, J. P. and Kumar, S. 2005. Evaluation of plant extracts for control of alternaria leaf spot of vicia faba. Ann. Pl. Protec. Sci. 13:213-214.

Malik, V. K., Singh, D. P. and Panwar, M. S. 2008. Management of spot blotch of wheat (Triticum aestivum) caused by Bipolaris sorokiniana using foliar sprays of botanicals and fungicides. Indian J. Agr. Sci. 78:646-648.

Nasir, A., Singh, V. K. and Singh, A. 2012. Management of maydis leaf blight using fungicides and phytoextracts in maize. Maize J. 1:106-109.

Oerke, E. C. 2006. Crop losses to pests. J. Agric. Sci. 144:31-43.

Payak, M. M. and Sharma, R. C. 1985. Maize diseases and their approach to their management. Trop. Pest Manage. 31:302310.

Reddy, T. R., Reddy, P. N., Reddy, R. R. and Reddy, S. S. 2013. Management of turcicum leaf blight of maize caused by Exserohilum turcicum in maize. IJSRP 3:1-4.

Saxena, S. C. 2002. Bio-Intensive integrated disease management of banded leaf and sheath blight of maize. In: Proceed of 8th Asian regional maize workshop: new technologies for the new millennium, pp. 380-388. Bangkok, Thailand.

Sharma, R. R., Gour, H. N., Bora, K. K. and Gaur, R. B. 2002a. Lipid peroxidation and defense related enzymes in maize infected by Rhizoctonia solani. Indian Phytopath. 55:486-487.

Sharma, R. C. and Rai, S. N. 1999. Chemical control of banded leaf and sheath blight of maize. Indian Phytopath. 52:94-95.

Sharma, R. C., Vasal, S. K., Gonzalez, F., Batsa, B. K. and Singh, N. N. 2002b. Redressal of banded leaf and sheath blight of maize through breeding, chemical and biocontrol agents. In: Proceed of the 8th Asian regional maize workshop: new technologies for the new millennium, pp. 391-397. Bangkok, Thailand.

Shekhar, M. and Kumar, S. 2012. Inoculation methods and disease rating scales for maize diseases. 2nd ed, Directorate of Maize Research, Pusa Campus, New Delhi. pp. 11-14.

Singh, R., Mani, V. P., Koranga, K. S., Bisht, G. S., Khandelwal, R. S., Bhandari, P. and Pant, S. K. 2004. Identification of additional sources of resistance to Exserohilum turcicum in maize (Zea mays L.). SABRAO J. Breed. Gen. 36:45-47.

Subedi, S. 2015. A review on important maize diseases and their management in Nepal. J. Maize Res. Dev. 1:28-52.

Wheeler, B. E. J. 1969. An introduction to plant diseases. John Wiley and Sons Limited, London.

White, D. G. 1999. Compendium of corn diseases. 3rd ed. American Phytopathological Society, St. Paul, MN, USA. 